\title{
Local Community Participation in Community Based Tourism in Kintamani and Their Impact to The Economy
}

\author{
Ni Luh Putu Agustini Karta ${ }^{1}$ \\ Triatma Mulya Institute of Economy, \\ Bali Indonesia, 2016 \\ agustinikputu@gmail.com \\ I Made Sukarsa ${ }^{2}$ \\ Faculty Economy, Udayana University, \\ Bali Indonesia, 2016 \\ loso_made@yahoo.co.id
}

\author{
Widi Hardini ${ }^{3}$ \\ Doctoral inTourism Program, Udayana \\ University, Bali Indonesia, 2016 \\ widihardini@gmail.com \\ I Ketut Putra Suarthana 4 \\ Triatma Mulya Institute of Economy \\ Bali Indonesia, 2016 \\ putra.suarthana@yahoo.com
}

\begin{abstract}
The purpose of this study was to determine and analyze the level of participation of local communities in CommunityBased Tourism (CBT) in Kintamani Destination, and their impact to the economy. The local communities are involved in tourism activities. Management of tourist destinations in Kintamani is legally under the supervision of the local tourism office. The government is always involved and provided with technical assistance and even funded to develop destinations. Toya Bungkah Spring Water, Historical Relief "Yeh Pulu", Cemeteries Trunyan and Buahan Tourism Village; are given full responsibility to manage it. But in tourist attraction likes Climbing Mount Batur, (because it includes aspects of mountains controls, nature preservation and the environment conservation), the government manage it $40 \%$ versus $60 \%$ share; between government and society. The level of local people participation is based on the theory of Public Participation Level (Tosun, 1999), that is categorized into spontaneous, induced and coercive. This study measured the level of participation by Tosun Theory (1999), then analyzed its impact on the economy of local communities. Methodology used in this research is quantitative analysis Partial Least Square (PLS). Sampling technique is a non-probability with purposive sampling. Respondents in this study were 52 members of local community groups whom involved in CBT activities in Kintamani. The findings were that tourism activities did not significantly influent local people participation, and significantly influent to economic impact. Local people participation did not significantly influent to economic impact. Participation of local community on each tourism activities generate income, providing employment, increase the amount of production, marketing network and promote the Kintamani destination to the world. The implications of this study are to raise the level of community participation in various tourism activities. Thus the local community's economy will improve, the standard of living and welfare of the people is also increasing. Limitations of this study only focus on the economic aspects; in fact, many other aspects that rose up as the impact of community participation in tourism activities. Social and cultural impact, preservation and conservation of the environment impact need to be further analyzed.
\end{abstract}

Key Words: tourism activities, participation, economy impact

\section{INTRODUCTION}

\section{Kintamani Tourism}

Kintamani is one of the most favorable tourism destination in Bali. There are several tourism activities in Kintamani, such as: Mount Batur climbing, Buahan tourism village bike tracking tour with seeing local community agriculture and fish farming, visiting luwak coffee agro tourism, visiting Yeh Puluh historical relief, visiting Trunyan traditional cemetery across the Batur Lake, and enjoying the spring waters at Toya Bungkah. Tourism activities in Kintamani all over managed by the local community (Community Based Tourism/CBT). The local community involvement in these tourism activities gain benefits and potential economic values, thereby support their welfare.

Kintamani tourism destination legally managed under the supervisions of the local government tourism office. The government are involved in every technical tourism activities and support the destination development funding. The full authority of tourism attraction management given by the government to the local community for a several tourism attraction such as Toya Bungkah spring waters, Yeh Puluh historical relief, Trunyan cemetery and Buahan tourism village. For Mount Batur climbing tourism attraction, government supervised the aspect of controlling the mountain, nature and environment. The percentage of $40 \%$ and $60 \%$ share managed between government and local community. There are varies of local community participation form in Kintamani tourism attraction. For example: bicycle rental, handicraft selling, Mount Batur climbing guide, Trunyan cemetery guardian, managing the natural spring waters, agriculture farming and fish farming. The entire community common activities is packed for tourism. 


\section{Participation Theory}

Local community involved direct or indirectly in its application. Tosun (1999) stated the participation of local community is based on theory of public participation level. This theory divides the participation categories into spontaneous participation, induction and compulsion (coercive). In Kintamani community-based tourism activities, not all local communities participant pleased and satisfied. Some of them were not ready, unable and compelled to participate, therefor they cannot prompted the service with heart. Thus also emerged result in a various tourist complaints. Such as rogue street seller, incoherent competing climbing guide, unprofessional waiters services at restaurant, and illogical tariffs.

The Journal of Multidisciplinary Research (IJMR) in 2015 researched and published about the tourist complaints paradigm and the government roles as well as the stakeholders in providing tourist services. The study was conducted with qualitative approach through informant interview and focus group discussion (FGD). Within this research is aimed to focus on measuring the level of local community participation of Kintamani community-based tourism activities and the economy impact.

In community-based tourism theory (CBT Principles, 2011), tourism village are the implementation of eco-tourism concept, requires the participation of local communities. The local community participation form include from the beginning of its process until improving the quality of life and destination development contribution. Kathiseran (2006), examined the elements of participation from its management aspect. For the conservation reasons and natural environment management, include mangroves and forest, the local community participation indispensable.

Cecil et al. (2010) researched the community-based tourism impact from quality of life aspects. The development of cultural tourism is highly considered as the best way to attract tourists, therefore the local communities gain economic benefits and its impact in improving their quality of life as a whole. Cecil et al. (2010) research finding affirm Addo (2011) statement of the economic benefits to local communities from the potential of coast, hotels and resorts located at the specific points of main cultural capital destinations. Another research finding by Henderson (2007) particularly relevant to the development of community-based tourism is attempt to popularize the local community traditional foods. The diversity of foods, flavor as the identifier of location, traditions and cultural diversity, primary and/or secondary prospectuses in a good way as well as challenge for tourism industry development (Henderson, 2007).

The roles and local community participation needed in all forms of tourism activities such as arts and culture, nature conservation, accommodation services, tourist foods and beverages, tour packages, and transportations. In the typology development model of community-based, Tosun (1999) classified several types of community participation into three main sectors and the subs. Three main parts are consists: spontaneous participation, coercive participation and induced participation.

According to Tosun (1999) model, spontaneous participation is equal to the level of population power model by Arnstein (1971), as well as the independent mobilization and interactive participation model by Pretty (1995). Suarthana (2015) reviewed the spontaneous participation as an ideal instrument representation, provides the managerial responsibility and society power. Encouragement participation in tourism as shown in Tosun (1999) model equal to community activities level at Arnstein (1971) model and equal to functional participation and participation with incentives material and participation through consultation from Pretty (1995) model.

The community seems to be the priority in this type of tourism development, however it's actually geared more to the needs of the decision makers, businessman and tourists. In details, Tosun (2006) combine theories of participation as listed in Table 1.

Table 1. Normative Typologies of Community Participation

\begin{tabular}{|c|c|c|c|}
\hline \multirow[t]{3}{*}{ Lovel I } & \multirow{3}{*}{$\begin{array}{l}\text { 7. Self-mobilization } \\
\text { 6.Interactive } \\
\text { Participation }\end{array}$} & 8. Citizen Control & \multirow{3}{*}{$\begin{array}{l}\text { Spontaneous participation: } \\
\text { bottom up; active and direct } \\
\text { participation, participation } \\
\text { in decision making, authentic } \\
\text { participation, self planning }\end{array}$} \\
\hline & & 7. Delegated power & \\
\hline & & 6. Partnership & \\
\hline \multirow[t]{3}{*}{ Lsvel 2} & $\begin{array}{l}\text { 5.Functional } \\
\text { participation }\end{array}$ & 5. Placation & \multirow{3}{*}{$\begin{array}{l}\text { Induced participation: top } \\
\text { down, passive, formal, mostly } \\
\text { indirect, degree of tokenism, } \\
\text { manipulation, pseudo } \\
\text { participation, participation } \\
\text { in implementation, sharing } \\
\text { benefit, device between } \\
\text { proposed alternatives and } \\
\text { feedback }\end{array}$} \\
\hline & $\begin{array}{l}\text { 4. Participationfor } \\
\text { material incentives }\end{array}$ & 4. Consultation & \\
\hline & $\begin{array}{l}\text { 3. Participation by } \\
\text { consultation }\end{array}$ & 3. Informing & \\
\hline \multirow[t]{2}{*}{ Lovel 3} & $\begin{array}{l}\text { 1. Passive } \\
\text { participation }\end{array}$ & 2. Therapy & \multirow{2}{*}{$\begin{array}{l}\text { Coercive participation: top } \\
\text { down, passive, mostly } \\
\text { indirect, formal, } \\
\text { participation in } \\
\text { implementation but not } \\
\text { necessarily sharing benefits, } \\
\text { choice between proposed } \\
\text { limited alternatives or no } \\
\text { choice, paternalism, non } \\
\text { participation, high degree of } \\
\text { tokenism and manipulation. }\end{array}$} \\
\hline & $\begin{array}{l}\text { 1. Manipulative } \\
\text { participation }\end{array}$ & 1. Manipulation & \\
\hline \multirow[t]{2}{*}{ Level 4} & \multicolumn{3}{|c|}{ Non Participation } \\
\hline & $\begin{array}{l}\text { Pretty's (1995) typology } \\
\text { of community } \\
\text { participation }\end{array}$ & $\begin{array}{l}\text { Arnstein's (1971) } \\
\text { typology of community } \\
\text { participation }\end{array}$ & $\begin{array}{c}\text { Tosun's (1999) typology } \\
\text { of community } \\
\text { participation }\end{array}$ \\
\hline
\end{tabular}

Sumber: Tosun (2006). 


\section{Economy Impact}

Experts argued that tourism is one of the economic resources that can assist people in improving well-being (Putra and Pitana, 2010; Suarthana, 2015). Tourism activities give economic benefits to the local community, not just the opportunity of gaining money exchanges with tourism services to their villages. The more tourists visit the community-based tourism attraction, the more goods and materials needed at their villages. Such as, to meet the physical needs, consumption or logistic, transportation, promotion and social communication within the community.

Thapa (2010; cited in Suarthana, 2015) researches in Nepal village resort explain that the tourism villages give positive economic impact. This is because of tourists stayed at their village feels as part of their family member and part of local community. Tourist made direct interaction with the local community. They learned local traditions and enjoyed the experience of village daily life, engaged with local community and cooking activities, and also consumed local foods. Baral et al., (2008; cited in Suarthana, 2015) research in Sirubari village tourism Nepal also found that tourist are willing to pay double in tourism village because the villagers maintain and protect the authenticity of natural environment and provide the optimal services. Therefore, tourism village and the variation of local community-based tourism activities with the environment and better services will achieve a positive economy impact to the local communities. This statement also supported by Putra and Pitana (2010) study of Candirejo tourism village in Central Java and some other tourism village in Bali as the way to poverty alleviation.

\section{METHOD}

Research on community based tourism in Kintamani implemented quantitative analysis with partial least square (PLS). The measured variable is the Tourism Activity (X1), People Participation (X2) and Economic Impact (Y). With a 15 Likert scale, structured questionnaire were distributed to 40 respondents who are competent and represent criteria. They are local communities whom involve in tourism activity in Kintamani. Probability sampling was conducted on 52 respondents consist of local communities that are divided into several groups based on their role (participation). Criteria respondents; a minimum age of 18 years, and was directly or indirectly involved in the tourism activities in Kintamani. The collected data is processed by using Partial Least Square (SmartPLS), in order to measure of public participation partially on the impact of economic. The hypothesis model on this research are:

H1: Tourism Activities (X1) positive and significantly influent the local community participation (X2).

$\mathrm{H} 2$ : Tourism activity (X1) positive and significantly influent to economic impact (Y).

H3: Community Participation (X2) positive and significantly influent to economic impact (Y).

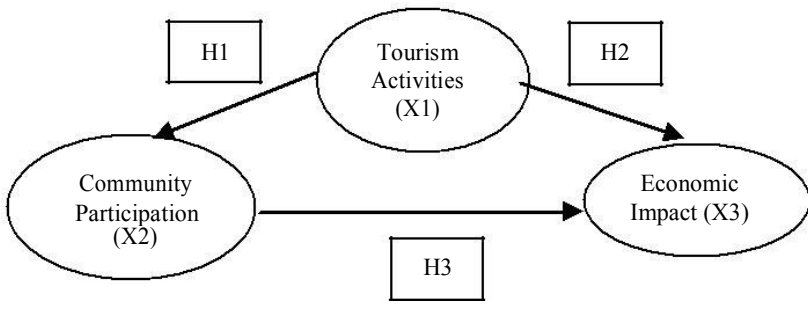

Figure 1: Research Model

\section{FINDING AND DISCUSSION}

\subsection{Overview of Kintamani and Surrounding Destinations}

Destinations of Kintamani, Lake Batur and its surroundings has known since the publication of books title Bali 1912, the author is Gregor Krause, after the first world's war in 1920.

Krause (2012) describes the attractiveness of Balinese Girls in Kintamani and introduce Bali as the Island of Paradise. This also triggers the arrival of European and American travelers in the 1920-30 decade. The story in this book became the forerunner of the future development of Lake Batur destinations.

Since the first Bali bombing tragedy on October 2002, the condition of this destination decline. The document assessment of Lake Batur, Kintamani, Merta (2012) state that Kintamani and surrounding areas shows that trend decline happen in tourist arrivals. Tourist lost the sense of security, complaint against the illegal bullying and the travel association (ASITA) warning guide to stop visit Lake Batur, Merta, (2012).

Kintamani is consist of fifteen villages in the surrounding area and Lake Batur. Zoning consists of: Region I includes: North Batur, Middle Batur and South Batur. Region II includes: Kintamani Village, Sukawana Village, Pinggan Village. Region III includes: Village Songan A, B and Village Blandingan. Region IV includes: Trunyan Village, Kedisan Village and Buahan Village. Region V includes: Songan Abang Village, Batu Dinding, Village Suter. Five people selected for each village as representative of local working group (LWG) that should be report to area coordinator (KORWIL). Each LWG consists of local communities, entrepreneur, expert team of local government, tourism associations, community leaders and the press. Each village has a different attractiveness, for example Kintamani Village famous at beautiful of local puppies, and oranges fruit of Kintamani tracking and climbing areas at Songan Village, birds at Kedisan Village, relief and historical stone at Batu Dinding Village dan many local culture and local custom and culture of Trunyan, hot water, archeology, geo park, which all have potential value, Agustini and Suarthana (2013). 


\subsection{Discussion}

Based on data was collected from 40 respondents, consisting of people who participate in tourism activities in Kintamani, analyzed then in more detail described as follows.

The analysis technique used in analyzing this problem is partial least square to calculate the tourism activities, community participation and the impact on economy. Partial least square analysis of data is describes as follows:

Characteristic of respondent involved in this research categories as follows:

\section{Table 2. Respondent Characteristic by Profession}

\begin{tabular}{|c|c|c|c|}
\hline No. & Profession & Amount & Percentage (\%) \\
\hline 1 & Tour Guide & 6 & $12 \%$ \\
\hline 2 & Hotel Staff & 18 & $35 \%$ \\
\hline 3 & $\begin{array}{c}\text { Food \& } \\
\text { handicraft Seller }\end{array}$ & 8 & $15 \%$ \\
\hline 4 & Art Worker & 9 & $17 \%$ \\
\hline 5 & Restaurant Staff & 4 & $8 \%$ \\
\hline 6 & $\begin{array}{c}\text { Farmer, } \\
\text { fisherman }\end{array}$ & 7 & $13 \%$ \\
\hline & Total & 52 & $100 \%$ \\
\hline
\end{tabular}

Source: Research Data 2016.

Table 3. Respondent Characteristic by Age

\begin{tabular}{|c|c|c|c|}
\hline No. & Age & Amount & Percentage (\%) \\
\hline 1 & $18-30$ & 10 & $19 \%$ \\
\hline 2 & $31-40$ & 9 & $17 \%$ \\
\hline 3 & $41-50$ & 18 & $34 \%$ \\
\hline 4 & $51-60$ & 15 & $29 \%$ \\
\hline & Total & 52 & $100 \%$ \\
\hline
\end{tabular}

Source: Research Data 2016.

According to data on Table 2, show that most profession of the local community involved in tourism activities is hotel staff, 35 percent and followed by arts workers, food and handicraft vendors as well as farmers and fishermen who make fish farms along Lake Batur.

In Table 3; age qualification of local community participated in community-based tourism in Kintamani, ware dominated by the age of 41-50 years, reaching 34 percent. Followed the next age category 51-60 years, $18-30$ years and 31-40 years are the smallest. This means that community-based tourism activities in Kintamani able to encourage people in various professions and in their productive age. This tourism activity becomes dominant occupation Kintamani society.

\subsubsection{Outer Model Measurement}

Table 4. Result of Outer Model 1

\begin{tabular}{|l|c|c|c|c|}
\hline \multicolumn{1}{|c|}{ Variables } & $\begin{array}{c}\text { original } \\
\text { sample } \\
\text { estimate }\end{array}$ & $\begin{array}{c}\text { mean of } \\
\text { subsamples }\end{array}$ & $\begin{array}{c}\text { Standard } \\
\text { deviation }\end{array}$ & T-Statistic \\
\hline Tourism Activities (X1) & & & & \\
\hline Diverse Activities & 0.876 & 0.884 & 0.025 & 35.360 \\
\hline Involve Community & 0.716 & 0.718 & 0.058 & 12.428 \\
\hline Benefit to Community & 0.754 & 0.742 & 0.078 & 9.622 \\
\hline Irigger new Problem & 0.438 & 0.447 & 0.166 & 2.633 \\
\hline Participation (X2) & & & & \\
\hline Spontaneous & -0.767 & -0.659 & 0.393 & 1.950 \\
\hline Induced & 0.823 & 0.725 & 0.379 & 2.171 \\
\hline Coercieve & 0.760 & 0.672 & 0.333 & 2.283 \\
\hline Economic Impact (Y) & & & & \\
\hline Increase Income & 0.632 & 0.640 & 0.069 & 9.175 \\
\hline Expand Employment & 0.838 & 0.827 & 0.049 & 16.950 \\
\hline Increase Quality of Life & 0.837 & 0.847 & 0.051 & 16.414 \\
\hline Open Market Capacity & 0.707 & 0.719 & 0.081 & 8.722 \\
\hline
\end{tabular}

Source: Statistic Analysis (2016)

Figure 2. Result of Outer Model1

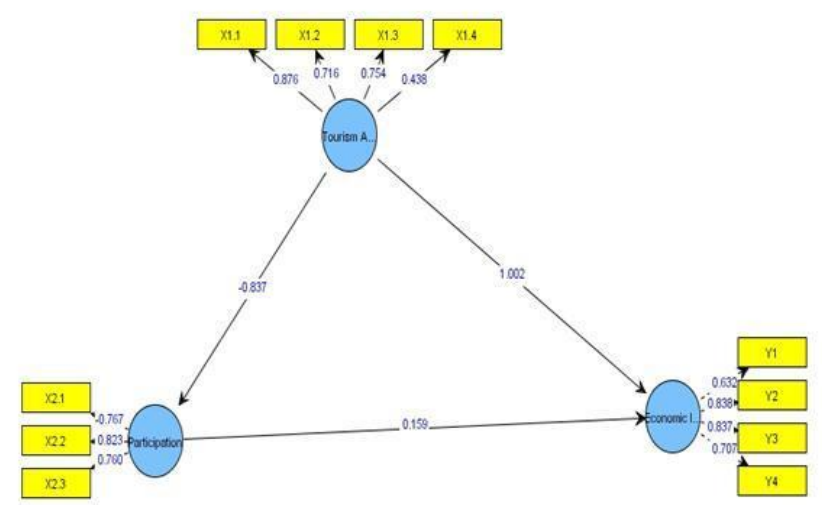

Source: Data Analysis (2016)

Table 5. Result of Outer Model 2

\begin{tabular}{|l|c|c|c|c|}
\hline \multicolumn{1}{|c|}{ Variable } & $\begin{array}{c}\text { Original } \\
\text { Sample } \\
\text { Estimate }\end{array}$ & $\begin{array}{c}\text { Mean of } \\
\text { Subsampl } \\
\text { es }\end{array}$ & $\begin{array}{c}\text { Standard } \\
\text { Deviation }\end{array}$ & T-Statistic \\
\hline Tourism Activities (X1) & & & & \\
\hline Diverse Activities & 0.870 & 0.872 & 0.035 & 24.527 \\
\hline Involve Community & 0.671 & 0.678 & 0.075 & 8.940 \\
\hline Benefit to Community & 0.828 & 0.831 & 0.043 & 19.329 \\
\hline Participation (X2) & & & & \\
\hline Induced Participation & 0.900 & 0.901 & 0.036 & 25.239 \\
\hline Coercive Participation & 0.820 & 0.809 & 0.081 & 10.183 \\
\hline Economic Impact (Y) & & & & \\
\hline Increase Income & 0.583 & 0.596 & 0.095 & 6.111 \\
\hline Expand Employment & 0.856 & 0.858 & 0.039 & 22.028 \\
\hline
\end{tabular}

Source: Statistic Analysis (2016) 
Figure 3. Result of Outer Model1

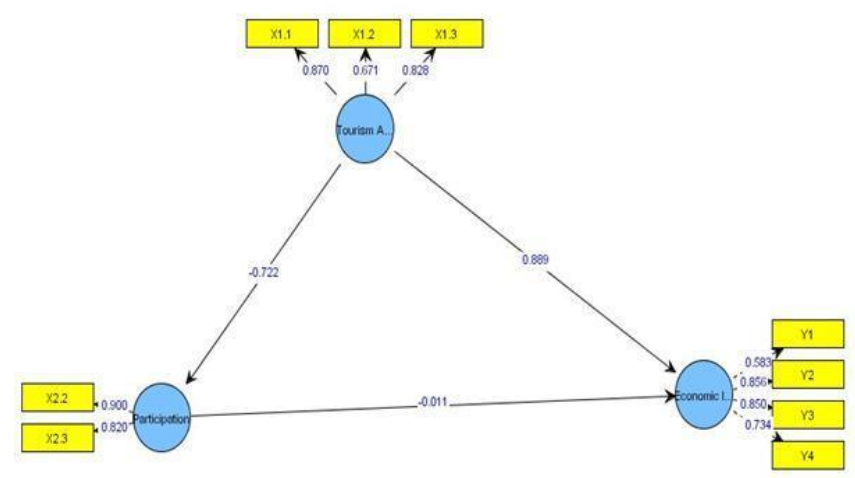

Source: Statistic Analysis 2016

Based on PLS analysis, in Table 4, it appears that there are two indicator variables which is not qualify with the estimation value and the average below 0.5 . Those indicator trigger a new problems and spontaneous. Consider these two indicators also did not qualified, therefore the adjustment is carried out. Result in the model 2 outer table as listed in table 5. The strongest indicator in this model is induced participation indicator. Similar to the previous and the following model produced adjustment shown in figure 2 and figure 3 .

\subsubsection{Discriminat Validity Measurement}

Performed by comparing the square root of average variance extracted (AVE) of each variable with the correlation between the other latent variables in the model. If the square root of average variance extracted ( $\sqrt{ }$ AVE) latent variable is greater than the correlation coefficient of latent variables, then this indicator variable have good discriminant validity. Recommended AVE value greater than 0.50. Table 4 below described more details.

Table 6 Discriminant Validity

\begin{tabular}{|c|c|c|c|c|c|}
\hline Variable & AVE & $\sqrt{ }$ AVE & $\begin{array}{c}\text { Correlation } \\
(\mathrm{X} 1)\end{array}$ & $\begin{array}{c}\text { Correlation } \\
(\mathrm{X} 2)\end{array}$ & $\begin{array}{c}\text { Correlation } \\
(\mathrm{Y})\end{array}$ \\
\hline $\begin{array}{c}\text { Tourism } \\
\text { Activity(X1) }\end{array}$ & 0.631 & 0.794 & 1.000 & & \\
\hline $\begin{array}{c}\text { Participation } \\
(\mathrm{X} 2)\end{array}$ & 0.741 & 0.861 & -0.722 & 1.000 & \\
\hline $\begin{array}{c}\text { Economic } \\
\text { Impact (Y) }\end{array}$ & 0.584 & 0.764 & 0.897 & -0.653 & 1.000 \\
\hline
\end{tabular}

Sources: Data analysis (2016)

\subsubsection{Composite Reliability Measurement}

This measurement designed to evaluate the reliability values between the block indicators of construct formed. The good composite reliability values is above 0.70 . More details shown in Table 7.
Table 7. Composite Reliability

\begin{tabular}{|c|c|}
\hline Variable & $\begin{array}{c}\text { Composite } \\
\text { Reliability }\end{array}$ \\
\hline $\begin{array}{c}\text { Tourism } \\
\text { Activities (X1) }\end{array}$ & 0.835 \\
\hline $\begin{array}{c}\text { Participation } \\
(\mathrm{X} 2)\end{array}$ & 0.851 \\
\hline $\begin{array}{c}\text { Economic } \\
\text { Impact (Y) }\end{array}$ & 0.846 \\
\hline
\end{tabular}

Source: Data analysis 2016

Based on Table 7 data shows that the three variables latent have value above 0.70 , therefore the indicator is reliable.

\subsubsection{Hypothesis Testing}

Based on the coefficient path calculation in Table 8, it shows that not all of the variables have a positive effect and significant.

\section{Tabel 8. Hypothesis Testing Results}

\begin{tabular}{|c|c|c|c|}
\hline $\begin{array}{c}\text { Variable } \\
\text { Relationship }\end{array}$ & $\begin{array}{c}\text { Bootstrapping } \\
\text { (Path } \\
\text { Coefficient) }\end{array}$ & $\begin{array}{c}\text { T- } \\
\text { Statistic }\end{array}$ & Remark \\
\hline $\begin{array}{c}\text { Tourism } \\
\text { Activities (X1) } \\
\text { Participation } \\
\text { (X2) }\end{array}$ & -0.727 & 8.816 & $\begin{array}{c}\text { Not } \\
\text { Significant }\end{array}$ \\
\hline $\begin{array}{c}\text { Tourism } \\
\text { Activities (X1) } \\
\text { Ecponomic } \\
\text { Impact (Y) }\end{array}$ & 0.894 & 12.327 & Significant \\
\hline $\begin{array}{c}\text { Participation (X2) } \\
\rightarrow \begin{array}{c}\text { Economic } \\
\text { Impact (Y) }\end{array}\end{array}$ & -0.016 & 0.121 & Significant \\
\hline
\end{tabular}

Source: Data analysis (2016)

The translation of hypothesis testing described as follows:

H1: Tourism Activities (X1) positive and significantly influent the local Community Participation (X2).

H1 hypothesis not proven.

Result shows the negative coefficient path (-0.727) with $\mathrm{T}$ statistic $=8.816(\mathrm{~T}$-statistic $>1,96)$, therefore Hypothesis 1 (H1) of tourism activities did not influent and significant to community participation. This result captures the idea to Kintamani local community and government. The various forms of tourism activities conducted by government have not been able to involve the entire community to participate. This finding is affirm of Tosun (2006) statement, that the tourism development seems to place local community as priorities, but it's actually more to satisfying the needs and wants of the 
decision makers, businessman and tourists. Limited human resources, instruments and networks, made the local communities less interested and unable to participate.

H2: Tourism Activities (X1) positive and significantly influent to economic impact (Y).

H2 Hypotesis proven.

Result shows the positive coefficient path (0.894) with Tstatistic $=12.327(\mathrm{~T}$-statistic $>1,96)$, therefore Hypothesis 2 (H2) of tourism activities positive influent and significant to economic impact. The result of this test explains that every communities involvement from the various tourism activities always bring a positive results to their economy. This result confirmed the research (Putra and Pitana, 2010; Suarthana, 2015). Local community participation brings economic benefits by increases their prosperity and quality of life.

H3: Community Participation (X2) positive and significantly influent to economic imoact (Y).

H3 Hypothesis not proven.

Result shows the negative coefficient path $(-0.016)$ with Tstatistic $=0.121(\mathrm{~T}$-statistic $>1,96)$, therefore hypothesis 3 (H3) of community participation negative influent and not significant to economic impact. In Kintamani tourism activities there are few of local community involve spontaneously or by their own volition. Most of them participate as the government instigation. For the local communities who are not involved or nor participate, the economy benefits of tourism activities does not affecting them. This kind of issues therefore will bring the gaps to the society and impact to the violations at tourism destination.

\section{CONCLUSION AND SUGGESTION}

Based on the quantitative analysis results on Kintamani community-based tourism activities, it can be concluded that:

a. Community-based tourism brings a positive value for the local community, environment, and cultural tradition and enrich the traditional food. Therefore, community-based tourism needs to be developed.

b. Tourism activities, community participation and economic improvement have not been fully achieved through community-based tourism programs. The limited information, low competence of local community, competitiveness, communication of local communities should be the priority to the government. Therefore, the expected economic impact would be appeared from the variation of community-based tourism activities on community participation and local community economy improvement.

c. The difference paradigm between local community and government also influent the strategy taking. The government promoting community-based tourism for increasing the local community welfare, however difference perception appears at the local community. It brings the gaps and low benefits of tourism development to the society.
Suggestion based on the results study:

a. Kintamani is one of the world tourism destinations. The captivation diversity makes this tourism destination visited. However, the limited competences of local community in serving the tourist makes it less likely to engaged in tourism activities. Government should prioritize this arise problem.

b. The stakeholders should provide their assistances and support the local community in order to succeeding the community-based tourism activities in Kintamani.

c. The academic participation urgently needed to provide their assistances, strengthening, doing more research and networking in order to optimize tourism activities. Thus the economic benefits of tourism activities will be felt by the local community.

d. This study limited to the aspect of participation and economic impact. Further research is needed in deeper and other aspects more focus on the purpose of Kintamani local community tourism.

\section{REFERENCES}

Addo, Edward. 2011. Diversification of the Tourist Landscape on Ghana's Atlantic Coast: Forts, Castles and Beach Hotel/Resort Operations in the Tourism Industry. Journal of Tourism Consumption and Practice Volume 3 No.1 2011 ISSN 1757-031X I

Agustini, Ni Luh Putu and Suarthana, I Ketut Putra. 2013. How Does Destination Management Improve Local People Participation. Proceeding of Hospitality Tourism and Research Practice. AITTEI Conference Malaysia.

Arnstein, R. S. 1971, Eight rungs on the ladder of citizen participation, S.E. Cahn, A.B. Passett (Eds.), Citizen participation effecting community change.,New York: Praeger Publishers, New York (1971). pp.: 69-91.

Cecil A.K., Y.Y. Fu, S. Wang, S. Avgoustis (2010) Cultural tourism and quality of life: The current issue and full text archive of this journal is available at www.emeraldinsight.com/0007-070X.htm Nanyang Technological University, Singapore

Henderson, Joan C. 2007. Food tourism reviewed, The current issue and full text archive of this journal is available at www.emeraldinsight.com/0007-070X.htm

http://mekongtourism.org/website/wpcontent/uploads/downloads/2011/02/CBT-HandbookPrinciples-and-Meanings-by-CBT-I-Thailand.pdf

Kathiresan, K. 2006. Peoples Participation, Centre of Advanced Study in Marine Biology Annamalai University.

Krause, G. 1912. One Hundred Years Later and Revitalization of Tourism Bangli . Department of Culture and Tourism Bangli Regency and STP Nusa Dua Bali . Denpasar. 27 September 2012 . 
Mertha, I Wayan . 2012. Evaluation of Cluster DMO Bali . Culture and Tourism Office Bangli regency .

Pretty, J. N. 1995. Participatory Learning for Sustainable Agriculture.World Development 23(8), Hal: 1247-1263.

Pretty, J.N. 1995. Regenerating Agriculture: Policies and Practice for Sustainability and Self-Reliance. Earthscan, London; National Academy Press, Washington - adapted from Adnan et al. 1992)

Putra, I.N.D. \& Pitana, I.G. 2010.Pariwisata Pro-Rakyat Meretas Jalan Mengentaskan Kemiskinan di Indonesia, Jakarta: Kementrian Kebudayaan dan Pariwisata Republik Indonesia., Jakarta.

Suarthana, I Ketut Putra. 2015. Impact of Community Participation on Village Tourism Management to Economy, Environment, Social and Culture. Dissertation of Doctoral Program on Tourism, Udayana University, Bali Indonesia.

Tosun, C. (2000). Limits to community participation in the tourism development process in developing countries, Tourism Management, 21: 613-633.

Tosun. C. (2006). Expected nature of communityparticipation in tourism development. Tourism Management, 27(3): 493-504.

Tosun.C. 1999. Towards a Typology of Community Participation in the Tourism Development Process.Anatolia 10(2): 113-134. 